\title{
AGRONOMIC PERFORMANCE OF SINGLE HEAD BROCCOLI CULTIVARS UNDER PROTECTED ENVIRONMENT IN TROPICAL CONDITIONS
}

Darley Tiago Antunes ${ }^{1}$, Santino Seabra Júnior ${ }^{1}$, Marcio Zanuzo ${ }^{2}$, Franciely Da Silva Ponce ${ }^{1}$, Jucimar Ferreira Neves ${ }^{3}$, Daiane Andréia Trento ${ }^{1}$, Rivanildo Dallacort ${ }^{1}$

\footnotetext{
${ }^{1}$ Universidade do Estado de Mato Grosso - UNEMAT. E-mail: darleytiago@ outlook.com; santinoseabra@ hotmail.com; francyponce@hotmail.com; daiatrento@gmail.com; rivanildo@unemat.com.br

${ }^{2}$ Universidade Federal de Mato Grosso - UFMT. E-mail: marcio.zanuzo@ gmail.com

${ }^{3}$ Universidade Federal da Grande Dourados - UFGD. E-mail: jucimarferreira @ globo.com
}

\section{ABSTRACT}

Growing broccoli in tropical regions is a challenge because higher temperatures delay plant development and consequently low yield. The aim of this study was to evaluate agronomic performance of single head broccoli cultivars under protected environment in tropical conditions. The experiment was laid out in a protected arc-type environment, covered with a 120 $\mu \mathrm{m}$ anti-UV-A and UV-B plastic film in a randomized block design (RBD) with four cultivars (BRO068, Imperial, Salinas, and TPC07118) were used, with six replications. It was evaluated: Fresh weight $\left(\mathrm{g}\right.$ plant $\left.{ }^{-1}\right)$, curd diameter $(\mathrm{cm})$, Yield (ton ha ${ }^{-}$ 1), plant height $(\mathrm{cm})$, cycle, inflorescence emission, the harvest period and adaptability. The visual aspect index and the commercial classification were also evaluated. In this study it can be concluded that all the materials are thermotolerant to greenhouse environmental, however, "Imperial" hybrid presented the best adaptation to crop yield with $7.69 \mathrm{tha}^{-1}$.

Keywords: Brassica oleracea var. Itálica L., tropical horticulture, thermotolerance, productivity

\section{DESEMPENHO AGRONÔMICO DE CULTIVARES DE BRÓCOLIS DE INFLORESCÊNCIA ÚNICA SOB AMBIENTE PROTEGIDO EM CONDIÇÕES TROPICAIS}

\section{RESUMO}

O cultivo de brócolis em regiões tropicais é um desafio, pois temperaturas elevadas prejudicam o desenvolvimento das plantas. Este trabalho teve como objetivo avaliar cultivares de brócolis do tipo inflorescência única sob ambiente protegido em condições tropicais. $\mathrm{O}$ cultivo foi realizado em ambiente protegido do tipo arco, coberto com filme plástico de $120 \mu \mathrm{m}$ anti UV-A e UV-B. Utilizou-se o delineamento experimental em blocos casualizados (DBC), com quatro cultivares (BRO068, Imperial, Salinas e TPC07118), com seis repetições. Foram avaliados: massa fresca da inflorescência (kg planta ${ }^{-}$ 
${ }^{1}$ ), diâmetro da inflorescência (cm), produtividade (ton ha-1 ${ }^{1}$, ciclo, emissão das inflorescências, o período de colheita e adaptabilidade, o índice de aspecto visual e a classificação comercial. Verificou-se nesse estudo que todos os materiais são termotolerantes e podem ser cultivados sob ambiente protegido, porém, entre os híbridos avaliados a cultivar "Imperial" apresentou melhor adaptabilidade às condições de cultivo apresentando maior produtividade com 7,69 ton ha- ${ }^{1}$

Palavras-chave: Brassica oleracea var. Itálica L., horticultura tropical, termotolerância, produtividade

\section{INTRODUCTION}

The broccoli (Brassica oleracea var. Itálica L.) is a species in which peduncles and flower buds are marketed, and can be divided into two groups: genotypes and / or cultivars with lateral shoots, called ramoso type, and those with Apex, called single inflorescence (VIDIGAL \& PEDROSA, 2007).

This species is original from the Mediterranean and is adapted to mild climate conditions. The genetic improvement of plants has worked to improve the adaptability of these species to situations of tropical climate (SEABRA et al., 2014). In Brazil these species are very widespread mainly in the South and Southeast regions, subtropical regions, due to the milder temperatures that allow the good development of the crop. However, the demand for the product has increased, thus needing to be produced in other regions of the country characterized as tropical.

In tropical regions, high rainfall and temperatures are limiting for broccoli production, because the development and flowering of the plant are impaired, leading to a decrease in the size and quality of the inflorescence (LALLA et al., 2010; SEABRA et al., 2014). This reduction in quality is attributed to irregular development of the florets, low compactness of the head and the appearance of green leafs in the inflorescences.

Previous studies carried out by Seabra et al. (2014) under field conditions with temperatures varying from 19 to $33^{\circ} \mathrm{C}$ verified the potential of production of single inflorescence broccoli using thermo-tolerant cultivars. One of the obstacles for the production of these materials was the conditions of high rainfall and high temperature, making necessary the use of protected environment seeking better productivity and smaller losses post-harvest mainly in the summer season.

Yield under umbrella protected environment systems is advantageous by controlling precipitation in addition to increasing the relative humidity of the air within the environment and reducing the internal temperature (VOLTAN et al., 2014). 
Studies with broccoli in tropical regions are scarce and it is necessary to develop technologies to the crop yield. These technologies can contribute to the profitability of the regional horticulture chain. For this, technologies like the use of greenhouses with system to control temperature and relative humidity are alternatives to these species as exploitation of their productive potential.

Therefore, the aim of this study was to evaluate single curd broccoli growth and development in protected environmental conditions of tropical climate.

\section{MATERIAL AND METHODS}

The study was developed from February 2 to August 6, 2015, in the experimental area of the State University of Mato Grosso State (UNEMAT), Nova Mutum campus-Mato Grosso, Brazil, located at coordinates $13^{\circ} 49$ '44 "S and 56 $04^{\circ} 56^{\prime} \mathrm{O}$, and elevation of 460 meters. There are two well defined seasons, where the dry season comprises the months of May to September and rainy periods are concentrated in the months from October to April (NOGUEIRA et al., 2010).

During the essay, the air temperature of the region was monitored, obtaining maximums ranging from 25 to $37.4{ }^{\circ} \mathrm{C}$, with a compensated average of $32.48{ }^{\circ} \mathrm{C}$ and minimum temperatures ranging from 13 to $23.5^{\circ} \mathrm{C}$ with compensated average of $18.77^{\circ} \mathrm{C}$ (INMET, 2015) (Figure 01).

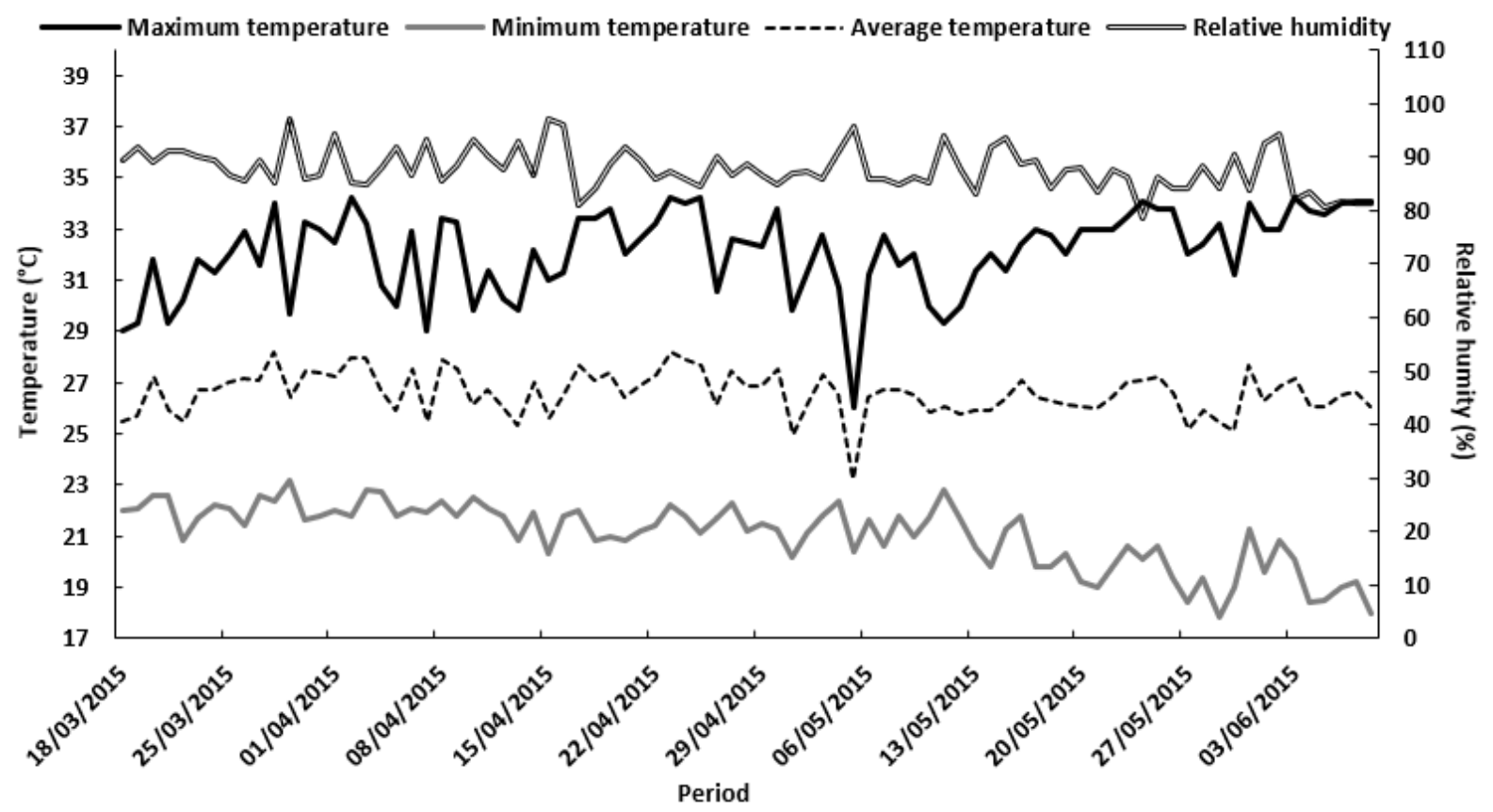

Figure 1. Maximum, minimum and average of temperature and relative humidity, in the period from 03/18/2015 to 06/08/2014 during time yield. (INMET, 2015). 
In this study, the internal temperature of the protected environment was monitored and checked and daily amplitude was obtained. Before trial planting, millet seeds were sown, and after 40 days, the plants were cut and left on the ground as protection to control weeds. Soil physical and chemical characteristics are presented as following: a) physical: sand $=750 \mathrm{~g} \mathrm{~kg}^{-1}$, silt $=62 \mathrm{~g} \mathrm{~kg}^{-1}$; Clay $=188 \mathrm{~g}$ $\mathrm{kg}^{-1}$ and b) chemical: M.O. $=1.6 \mathrm{~g} \mathrm{dm}^{-3} ; \mathrm{pH} 7.3 ; \mathrm{P}=117.3 \mathrm{mg} \mathrm{dm}^{-3} ; \mathrm{K}=204 \mathrm{mg} \mathrm{dm}^{-3} ; \mathrm{Ca}=3.2$ cmolc $\mathrm{dm}^{-3} ; \mathrm{Mg}=1.3 \mathrm{cmolc} \mathrm{dm}^{-3} ; \mathrm{Al}=0.0 \mathrm{cmolc} \mathrm{dm}^{-3} ; \mathrm{CTC}=6.02 \mathrm{cmolc} \mathrm{dm}^{-3} ; \mathrm{V}=83 \%$.

To mineral fertilization it was applied $60 \mathrm{Kg} \mathrm{N} \mathrm{ha-}^{1}, 200 \mathrm{Kg} \mathrm{P}_{2} \mathrm{O}_{5} \mathrm{ha}^{-1}$ and $120 \mathrm{KgK}_{2} \mathrm{O} \mathrm{ha}^{-1}$, using as source urea $(44 \% \mathrm{~N})$, potassium chloride $\left(58 \% \mathrm{~K}_{2} \mathrm{O}\right)$ and single superphosphate $\left(18 \% \mathrm{P}_{2} \mathrm{O}_{5}\right)$, in addition to $10 \mathrm{t} \mathrm{ha}^{-1}$ of chicken manure according to Ribeiro et al. (1999).

Broccoli was sowed in trays of expanded polystyrene filled with commercial substrate Vivatto ${ }^{\circledR}$ and the seedlings were transplanted at 43 days after sowing (DAS).

Top dressing fertilization was carried out by using, $200 \mathrm{Kg} \mathrm{N} \mathrm{ha}^{-1}$ and $120 \mathrm{Kg} \mathrm{K}_{2} \mathrm{O} \mathrm{ha}^{-1}$ using urea $(44 \% \mathrm{~N})$ and potassium chloride $\left(58 \% \mathrm{~K}_{2} \mathrm{O}\right)$ respectively, distributed in seven periods $(8,15,24$, 35, 43, 54, and 62 days after transplantation - DAT). Foliar fertilization with boric acid (17\% B) and ammonium molybdate (54\% Mo) at concentrations of $1 \mathrm{~g} \mathrm{~L}^{-1}$ and $0,5 \mathrm{~g} \mathrm{~L}^{-1}$ respectively, was applied at 15, 30 and 45 DAT according to Ribeiro et al., (1999).

Experimental setup was carried out in a RDB mode with six replications with sixteen plants in each plot. As useful analysis area, six plants inner the plot were collected. The treatment was composed by four single head broccoli cultivars (BRO068, Imperial, Salinas, and TPC07118).

The plants were arranged in double spacing of $0.8 \mathrm{~m}$ between double lines, 0.5 meter between rows and $0.5 \mathrm{~m}$ between plants, in a total of 30.769 plants $\mathrm{ha}^{-1}$. The irrigation used was drip type installed "in line", with $0.5 \mathrm{~m}$ emitter distance. Soil moisture was controlled using metal vacuum gauge tensiometers to maintain soil tension at $15 \mathrm{kPa}$ at $0.2 \mathrm{~m}$ depth according to Tangune et al. (2016). The monitoring of the internal temperatures of the protected environment was performed daily, from March 18 to June 3, 2015, using the Icel Manaus HT-208 thermo-hygrometer, installed in the center of the protected environment, at a height of $1 \mathrm{~m}$ from leaves canopy.

As parameter evaluation, there were analyzed Yield (ton ha- ${ }^{1}$ ); curd diameter (cm plant-1), curd fresh mass $\left(\mathrm{kg} \mathrm{plant}^{-1}\right)$, plant height $(\mathrm{cm})$, cycle (days between sowing and harvest), curd emission (days between sowing and emission), and harvest period (days between harvesting the first and last inflorescence). It was also evaluated the visual aspect index through grading of notes, the same method 
adopted by Seabra Jr. et al. (2014). It was considered (1) = non-commercial, extremely defective, $2=$ defective commercial, 3 = moderately defective, $4=$ slightly defective, $5=$ no apparent defects. For curd classification it was used a graduate scale changing from 0 to 5 adapted from Pizetta et al. (2005).

For adaptability index, factors such as fresh curd mass and total fresh mass of the plant were correlated. Results considering moderate or strong were used as a parameter of adaptability to tropical conditions.

For statistical analysis, variance analysis was performed by F-test $(\mathrm{p}<0,05)$ and when significant submitted to Scott-Knott using Assistat Version 7.7 Beta (PT) software (SILVA et al., 2009). To evaluate adaptability to the cultivars, Pearson correlation was applied between total fresh mass and fresh curd mass, the correlation calculation was performed using the statistical analysis software R (R, 2011).

\section{RESULTS AND DISCUSSION}

At the end of final cycle, it was verified that there was a statistical difference between the variables analyzed, there was a significant difference between the evaluated genotypes. For the variable weight mass, the imperial cultivar was superior to TPC07118, BRO68 and Salinas with values of 0.230; $0.197 ; 0.187$; and $0.132 \mathrm{~kg}$ of plant-1, respectively (Table 1 ).

Table 1. Fresh Weight (FW) $\left(\mathrm{kg} \mathrm{plant}^{-1}\right)$, Yield (ton ha- $\left.{ }^{1}\right)$ Curd Diameter (CD) (cm), Visual Aspect Index (IAV),

\begin{tabular}{ccccc}
\hline Cultivars & FW & Yield & CD & ÍAV \\
\hline Imperial & $0,231^{\mathrm{a}}$ & $7,69^{\mathrm{a}}$ & $12,8^{\mathrm{a}}$ & $3,3 \mathrm{~b}$ \\
TPC07118 & $0,197 \mathrm{~b}$ & $5,5 \mathrm{~b}$ & $12,5^{\mathrm{a}}$ & $1,7 \mathrm{c}$ \\
Salinas & $0,132 \mathrm{c}$ & $4,38 \mathrm{c}$ & $10,5 \mathrm{~b}$ & $4,2^{\mathrm{a}}$ \\
BRO68 & $0,187 \mathrm{~b}$ & $6,21 \mathrm{~b}$ & $13,1 \mathrm{a}$ & $2,9 \mathrm{~b}$ \\
\hline CV $(\%)$ & 11,49 & 11,49 & 6,09 & 17,42 \\
\hline
\end{tabular}

Means followed by different letters in the column are different by Scott-Knott test $(\mathrm{p}<0.05)$

In studies developed by other authors, such as: Seabra et al. (2014) in the region of Cáceres-Mato Grosso state with an average of $26.3^{\circ} \mathrm{C}$ in open field verified for broccoli cultivars BR068, Imperial, Salinas means fresh weight of 0.90; 0.70; $0.72 \mathrm{~g}$ of plant $^{-1}$, respectively, Lalla et al. (2010) in another tropical region, studying the adaptability, cultivar BR068 of fresh weight of $0.48 \mathrm{~g}_{\text {of }}$ plant $^{-1}$ was verified with average temperature of $22.4^{\circ} \mathrm{C}$. 
Similar to fresh weight, the yield of broccoli presented the same behavior. In this study, Imperial cultivar presented the highest yield followed by BRO68, TPC07118 and Salinas with means of 7.69; 6.21; 5.5; and 4.38 ton $\mathrm{ha}^{-1}$. Seabra et al. (2014), studying yield behaviour under tropical regions in an open field conditions, verified that the cultivars BR068, Imperial and Salinas verified good productivity with temperature average of $26,3^{\circ} \mathrm{C}$ with yields of $19.93,26.18$ and 36.09 ton ha $^{-1}$, respectively for each cultivar cited. Lalla et al. (2010), in another region characterized as tropical climate, verified to BR068 values of 9.64 ton ha- ${ }^{1}$ under temperature of $22.4^{\circ} \mathrm{C}$. The results obtainedare lower than those obtained by Seabra et al. (2014) and Lalla et al. (2010).

In relation to curd diameter (CD), cultivars evaluated ranged from 10.58 to 12.87 centimeters. Imperial, TPC07118 and BRO68 materials did not differ statistically from each other, but curds diameter was higher than Salinas cultivar (Table 1). Recent studies assayed by Lalla et al. (2010), Seabra et al. (2014) and Schiavon (2008), obtained higher results in curd diameter. The higher results may be related to the developmental conditions of the culture. In cauliflower, another brassica similar in behavior to broccoli, Zanuzo et al. (2013) verified positive correlation of curd diameter with stem diameter, leaf area, shoot biomass and fresh weight.

Seabra et al. (2014), studying commercial hybrids as Imperial, Salinas and BRO68 obtained curd diameter of 18.9; 20.8; and $21.4 \mathrm{~cm}$ respectively, values much higher than those in the present study, which were 12.87; 10.58; and 13.11 for the hybrids reported above. The explanation for this fact is in the parameter temperature where it is emphasized that high temperatures reduce curd development (TREVISAN et al. 2003).

The visual index aspect is an important parameter of broccoli curd quality, since it defines consumer acceptance (SEABRA et al. 2014). Salinas hybrid showed better values, despite lower yields. The Imperial cultivar showed higher productivity and a satisfactory visual index, and could be well accepted by marketable place (Table 1).

In this study, the visual aspect of Salinas and Imperial cultivars was smaller than those obtained by Seabra et al. (2014). This attribute is related to the different temperatures found during each essay, and the average ambient temperature obtained by this author varied from 19.2 to $33.4{ }^{\circ} \mathrm{C}$, being this study carried out in an open field, temperatures those inferiors occurring in this work 21.25 to $38.67^{\circ} \mathrm{C}$. This condition of temperature explains the difference on data analysis, because with high temperatures incidence the development and quality of the curds are impaired. 
In brassicas the main factor to limit growth and development of fresh curd mass is temperature. In this study, average temperature was $29,98^{\circ} \mathrm{C}$. According to May et al. (2007) and Trevisan et al. (2003) temperature is an important zoning attribute for growing materials because it is able to expressing maximum yield potential. Under tropical regions, it is common to note during the adaptability of the materials enhancing leaves number and consequently high index of leaf area (ZANUZO et al. 2013; DA PENHA RIBEIRO et al. 2017). This physiological change of the plant would be a compensation and/or advantage of photosynthetic adaptation apparatus to maintaining or established curd fresh weight.

The use of environmental protected conditions can increase internal temperature and modify physiological and biochemical characteristics in the plants. (PURQUERIO \& TIVELLI, 2006), leading to stop or reduce curd growth and development, leaves inner the curd, hollow stem, and reduce curd compactness reducing yield and quality (BJORKMAN \& PEARSON, 1998).

In this study the temperature clearly influenced the development of the materials studied not only by aerial temperature but by the soil too (Figure 2).

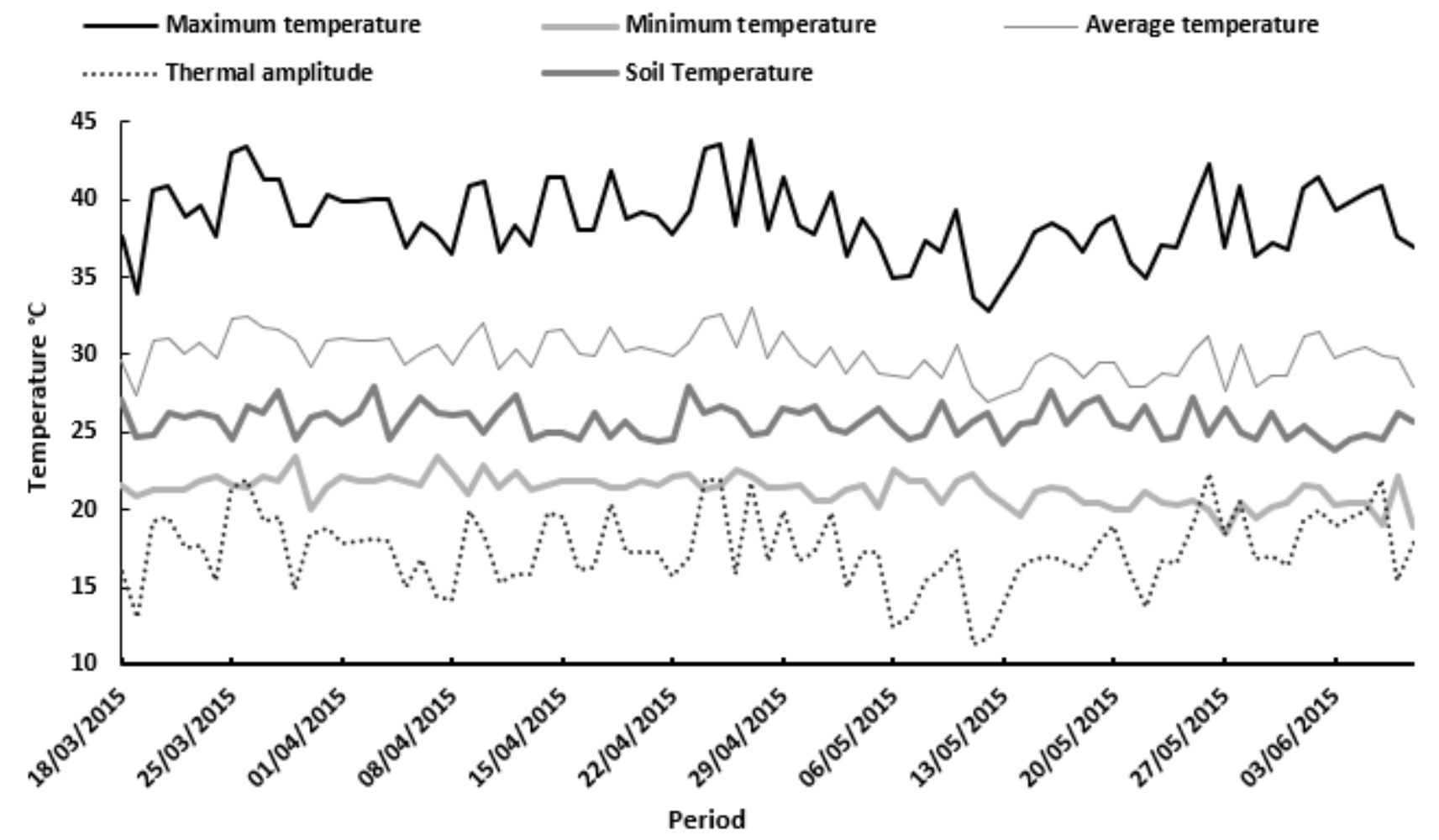

Figure 2. Maximum, average, minimum, soil temperature and thermal amplitude $\left({ }^{\circ} \mathrm{C}\right)$ of the protected environment in the period from 03/18/2015 to 06/08/2014. Nova Mutum, 2015. 
These conditions to brassica family can change growth and development by limiting symbioses interaction between microorganisms and nutrient leading to a reduce of assimilation and translocation and affect the plant development. Curiously to the factor temperature observed, all the materials developed curd emission, therefore, low fresh weight was observed for all cultivars. This low fresh weight is linked to the thermal stress factor.

These temperatures are much higher than those indicated as ideal for the species and according to Trevisan et al. (2003), the ideal average temperature for the development of broccoli is 15 to $18{ }^{\circ} \mathrm{C}$ with maximum of $24^{\circ} \mathrm{C}$. Schiavon (2008) reported that plant growth is inappropriate with temperatures above $28^{\circ} \mathrm{C}$ by limit plant growth as well as to change between vegetative and reproductive stage.

One of the desired effects in the cultures is delay on production characterized by precocity. In our study, TPC07118 and Imperial materials presented a shorter cycle, but did not differ between them, with values of 106,33 and 105,5 statistically differing only from cultivars BRO68 and Salinas, respectively, with values of 112,37 and 119,94. According to patent holders of these materials the average cycle is 90 , 100, and 105 days for hybrids BR068, Salinas, Imperial, and TPC07118, respectively (Table 2).

Table 2. Means of Cycle, Curd emission, and harvest time to each hybrid analyzed

\begin{tabular}{cccc}
\hline Hybrids & Cycle (Days) & Curd Emission & Harvest time \\
\hline Imperial & $105,51 \mathrm{a}$ & $90,49 \mathrm{a}$ & $14,97 \mathrm{a}$ \\
TPC07118 & $106,33 \mathrm{a}$ & $89,13 \mathrm{a}$ & $17,19 \mathrm{a}$ \\
Salinas & $119,94 \mathrm{c}$ & $107,41 \mathrm{c}$ & $12,52 \mathrm{a}$ \\
BRO68 & $112,37 \mathrm{~b}$ & $99,05 \mathrm{~b}$ & $14,69 \mathrm{a}$ \\
\hline CV $(\%)$ & 2,52 & 2,45 & 15,07
\end{tabular}

Means followed by different letters in the column different by the Scott-Knott test with $(\mathrm{p}<0.05)$

Studying broccoli type single head, Lalla et al. (2010) obtained culture cycle from 89 to 116 days and Melo et al. (2010) observed cycles from 87 to 128 days. Seabra et al. (2014) in their study obtained cycles from 85 to 108 days, where the cultivar was the most precocious. In this study, crop cycle results ranged from 105.5 to 119.94 days after sowing, with the Imperial and TPC07118 materials being similar with the shortest cycles. The Salinas cultivar presented the longest cycle (Table 2). 
The Imperial cultivar showed flowering beginning at 90 days after sowing, followed by TPC07118, Salinas and BRO68 materials respectively. For harvest time there was no statistical difference between the hybrids of this study (Table 2).

In this study it was verified cycle means of 111 days, based on the four cultivars object of study, and to curd emission the time required by the culture was of 96.52 days. These values observed are so important to knowledge of the culture and better applicability in the production systems. Farnham \& Bjorkman (2010), analyzing abiotic stresses concluded that temperature affect its cycle and yield. This information can be confirmed when verifying the great variation of results found in this study when compared to other authors.

Another important factor analyzed in this study was the commercial classification of inflorescence (Table 3).

Table 3. Commercial classification of inflorescence.

\begin{tabular}{|c|c|c|c|c|c|c|}
\hline \multirow{3}{*}{ Cultivars } & \multicolumn{6}{|c|}{ Class } \\
\hline & 1 & 2 & 3 & 4 & 5 & 6 \\
\hline & \multicolumn{6}{|c|}{$\%$ Inflorescence } \\
\hline Imperial & 47,2 & 44,44 & 5,55 & 2,77 & - & - \\
\hline BR 068 & 47,2 & 38,88 & 8,33 & 5,55 & - & - \\
\hline Salinas & 83,33 & 16,66 & - & - & - & - \\
\hline ТPC 07118 & 44,44 & 52,77 & 2,77 & - & - & - \\
\hline
\end{tabular}

Suggestion for classification of broccoli, based on the diameter in $\mathrm{cm}: 1=<12,0$ (Mini size); $2=12.0$ to $<15.0$ (very small size); $3=15.0$ to $<18.0$ (small size); $4=18.0$ to $<21.0$ (mean size); $5=21.0$ to $<24.0$ (large size); and $6=\geq 24.0$ (very large size), (-) no observation into the class. Adapted from PIZETTA et al., (2005).

The analysis of this aspect becomes important to determine if the genetic materials studied besides being adaptable to the conditions of tropical crops have capacity and quality to meet the demands of the consuming market. Another important factor analyzed in this study was the commercial classification of inflorescence (Table 3).

To the classification of "very small", TPC $07118 \mathrm{cv}$. presented more percent values followed by Imperial, BR 068 and Salinas. To "Small” classification BR 068 had the highest values, followed by Imperial and TPC 07118. To “medium” classification, only BR 068 and Imperial hybrids presented data, therefore, BR 068 was higher than it. 
In order to provide a better understanding of the adaptability of materials, pearson correlation between the MF and MFF wa applied. (Table 4).

Table 4. Pearson correlation for Fresh curd weight (MFI), Fresh leaf mass (MFF) and curd diameter (DI)

\begin{tabular}{ccccc}
\hline Cultivars & MFIxMFF & $\mathrm{R}$ & MFIxDI & $\mathrm{R}$ \\
\hline Imperial & $0,3759^{*}$ & Weak & $0,6867^{*}$ & Moderate \\
TPC 07118 & $0,2015^{*}$ & Weak & $0,5909^{*}$ & Moderate \\
Salinas & $0,4911^{*}$ & Moderate & $0,8051^{*}$ & Strong \\
BR068 & $0,5120^{*}$ & Moderate & $0,7743^{*}$ & Strong \\
\hline
\end{tabular}

Interpretation of Pearson's correlation (+ or-); 0.00 to 0.19 (very weak); 0.20 to 0.39 (weak); 0.40 to 0.69 (moderate); 0.70 to 0.89 (strong); 0.89 to 1.00 (very strong); * Significant with $\mathrm{p}<(0,05)$

Pearson correlation was performed between MFI and MFF. For these variable, a weak correlation was observed for Imperial and TPC07118 hybrids and moderate for BR068 and Salinas respectively. Pearson correlation between MFI and DI was analyzed, a strong correlation was found for Salinas and BR068 hybrids and moderate for Imperial and TPC07118 (Table 4). These data show that climatic conditions change behaviour of broccoli cultivars.

The characteristics analyzed for harvest in general can vary greatly according to the genetic material, as well as the climatic conditions.

The data of this study show a great variation and discrepancy regarding the data found by other authors mentioned above. This is due to the climatic conditions observed throughout this study, where there was the occurrence of high temperatures accompanied by incidence of pests and diseases during the essay. This typical climate of tropical climate, however these results obtained are acceptable and promising considering its applicability to the tropical climate.

According to the results, any single head broccolis cultivars have potential to be commercially explored under tropical conditions. Besides of climatic conditions not being the best to development of broccoli, all the materials presented curd formation and reach final cycle. More studies with reference to adaptability followed by period, yield systems and nutritional management should be carried out to maximize high yield and commercial quality to broccoli in regions under tropical conditions. 


\section{CONCLUSION}

This study can conclude that all the materials are thermotolerant to environmental protected however, "Imperial" hybrid presented the best performance to the crop and presenting higher yield.

\section{REFERENCES}

BJORKMAN, T.; PEARSON, K. 1998. High temperature arrest of inflorescence development in broccoli (Brassica oleracea var. italica L.). Journal of Experimental Botany, Oxford v.49, p.101-106.

CECÍllo, A. B. F.; SCHIAVON, J. A. A.; CORTEZ, J. W. 2012. Produtividade e classificação de brócolos para indústria em função da adubação Nitrogenada e potássica e dos espaçamentos entre plantas. Horticultura Brasileira, Brasília, v.30: p.12-17.

DA PENHA RIBEIRO, L. M.; ZANUZO, M. A. R.; VIEIRA, C. V. I.; JUNIOR, S. S.; JUNIOR, F. F. 2017. Cauliflower quality and yield under tropical conditions are influenced by boron fertilization. African Journal of Agricultural Research, Níger, v.12, n.11, p.1045-1053. Available at: < http://www.academicjournals.org/journal/AJAR/article-abstract/FC6F5A363304>. (Access in September, 2017).

FARNHAM, M. W.; BJORKMAN, T. 2010. Breeding vegetables adapted to high temperatures: A case study with broccoli. HortScience, Alexandria, v.46, n.8, p.1093-1097.

IBGE - Instituto Brasileiro de Geografia e Estatística. 2006. Censo Agropecuário. Available in; <http://www.ibge.gov.br/home/estatistica /economia/agropecuaria/censoagro/2006/ agropecuario.pdf $>$. (Access in march 2015).

INMET - Instituto Nacional De Meteorologia. 2015. Dados de temperatura máximas, médias e mínimas/estação Sao Jose Do Rio Claro, MT. Available in: <http://www.inmet.gov. br/projetos/rede/pesquisa/gera_serie_txt.php? \&mRel. Estacao $=83267 \&$ btnProcesso $=$ serie $\&$ mRelDtInicio=02/02/2015\&mRelDtFim $=06 / 08 / 2015 \& m$ Atributos $=, 1,1,,,,,,,,,, 1,,,>$. (Access in February, 2016).

LALLA, J. G.; LAURA, V. A.; RODRIGUES, A. P. D. C.; SEABRA, S. J.; SILVEIRA, D. S.; ZAGO, V. H.; DORNAS, M. F. 2010. Competição de cultivares de brócolos tipo cabeça única em Campo Grande. Horticultura Brasileira, Brasília, v.28: p. 360-363.

MAY, A.; TIVELli, S. W.; VARGAS, P. F.; SAMRA, A. G.; SACCONI, L. V.; PINHEIRO, M. Q. 2007. A cultura da couve-flor. Boletim Técnico IAC, Campinas, v.200, p.1-36.

MELO, R. A. C.; MADEIRA, N. R.; PEIXOTO, J. R. 2010. Cultivo de brócolos de inflorescência única no verão em plantio direto. Horticultura Brasileira, Brasília, v.28: 23-28.

NOGUEIRA, S. F.; GREGO, C. R.; QUARTAROLI, C. F.; ANDRADE, R. G.; HOLLER, W. A.; VITAL, D. M. Estimativa de estoque de carbono em sistema de produção de soja na região norte mato-grossense. Embrapa Monitoramento por Satélite-Artigo em anais de congresso (ALICE). In: CONGRESSO BRASILEIRO DE CIÊNCIA DO SOLO, 33., 2011, Uberlândia, MG. Anais... Uberlândia, MG: CBCS, 2011.

PERUCH, L. A. M.; MICHEREFF, S. J.; ARAÚJO, I. B. 2006. Levantamento da intensidade da alternariose e podridão negra em cultivos orgânicos de brássicas em Pernambuco e Santa Catarina. Horticultura Brasileira, Brasília, v.24, n.1, p.464-469.

PIZETTA, L. C.; FERREIRA, M. E.; CRUZ, M. C. P.; BARBOSA, J. C. 2005. Resposta de brócolis, couve-flor e repolho à adubação com boro em solo arenoso. Horticultura Brasileira, Brasília, v.23, n.1, p.51-56. 
PURQUERIO, LUIS FELIPE VILLANI; TIVELLI, S. W. 2006. Manejo do ambiente em cultivo protegido. Instituto Agronômico de Campinas IAC, Centro de Horticultura. Campinas, v.2, p.1529.

R, Development Core Team. R: A language and environment for statistical computing. R Foundation for Statistical Computing, Vienna, Áustria. 2011. Avaliable in: 〈http://www.R-project.org/.>.

RODRIGUES, R. R.; PIZETTA, S. C.; OLIVEIRA, H. M.; REIS, E.F.; TEIXEIRA, G. A. 2013. Desenvolvimento inicial de brócolis em diferentes disponibilidades hídricas. Enciclopédia Biosfera, Goiânia, v.9, n.17, p.1041-1050.

RIBEIRO, A. C.; GUIMARAES, P. T. G.; ALVAREZ, V. H. V. 1999. Recomendação para o uso de corretivos e fertilizantes em Minas Gerais - $5^{\circ}$ Aproximação. Viçosa: Comissão de Fertilidade do Solo do Estado de Minas Gerais, Viçosa, p, 359.

SEABRA, S. J.; NEVES, F. J.; DIAS, E. D. L.; SILVA, B. L.; NODARI, E. D. I. 2014. Desempenho de cultivares de brócolis de inflorescência única em condições de altas temperaturas. Horticultura Brasileira, Brasília, v.32, n.04, p.497-503.

SEABRA, S. J.; LALLA, J. G.; GOTO, R.; MARINGONI, A. C.; VILLAS BOAS, R. L.; ROUWS, J. R. C.; ORIANI, E. E. 2013. Suscetibilidade à podridão negra e produtividade de brócolis em função de doses de nitrogênio e potássio. Horticultura Brasileira, Brasília, v.31, n.3, p.426-431.

SILVA, F. A. S.; AZEVEDO, C. A. V. 2009. Principal Components Analysis in the Software AssistatStatistical Attendance. In: World congress on computers in agriculture, 7, Reno-NV-USA: American Society of Agricultural and Biological Engineers.

SCHIAVON, J. A. A. 2008. Produtividade e qualidade de brócolos em função da adubação e espaçamento entre plantas. Jaboticabal UNESP, p.67.

TANGUNE, B. F.; PEREIRA, G. M.; DE SOUSA, R. J.; GATTO, R. F. 2016. Response of broccoli to soil water tension under drip irrigation. Semina: Ciências Agrárias, Londrina, v.37, n.1, p.7-16.

TREVISAN, J. N.; MARTINS, G. A. K.; DAL'COL, A. L.; CASTAMAN, C.; MARION, R. R.; TREVISAN, B. N. 2003. Rendimento de cultivares de brócolis semeados em outubro na região centro do Rio Grande do Sul. Ciência Rural, Santa Maria, v.33, p.233-239.

VIDIGAL, S. M.; PEDROSA, M. W. 2007. Brócolos (Brassica oleracea. L. var. itálica). In: Paula Júnior TJ, Venzon M. (orgs). 101 Culturas - Manual de Tecnologias agrícolas. Belo Horizonte - MG: EPAMIG. p. 175-178.

VOLTAN, D. S.; BARBOSA, R. Z.; MARTINS, J. E. M. P. 2014. Variabilidade espacial da umidade relativa do ar no interior de uma casa de vegetação em clima tropical. Revista Brasileira de Ciências Agrárias, Pernambuco, v.9, n.2, p.251-257.

ZANUZO, M. R., RIBEIRO, L. M., LANGE, A., MACHADO, R. A. F., MASSAROTO, J. A. 2013. Desempenho agronômico de genótipos de couve-flor nas condições edafoclimáticas de Sinop. Horticultura Brasileira, Brasília, v.31, p.332-337. 